\title{
TEKSTUR BARU STUDI ISLAM; PROTOTIPE DIALEKTIKA AGAMA DAN REALITA
}

\section{Hijrian A. Prihantoro}

Fac. Comparative Law, The World Islamic Sciences\& Education University (W.I.S.E), Yordania.

Email: hijriantoro@gmail.com

\section{Abstract}

Islam is not mean just a religion but a civilization. The expectation for Islamic inaugural re-experience on the contemporary era is a major occupation for today's thinkers. The efforts of reconstruction of the religiousness understanding is the main idea which cannot be avoided because the event of Islamic Studies contest strives to inculcate sensitivity towards the diversity of the meaning of religious text. So, the attempts to present a new reading of the classical Islamic corpus is a necessary activity. It is intended that human values which have precipitated can be raised and be realized. If on the initial period of Islam, the Prophet PBUH and the Companions called out to create a single society, it is now the opposite; plural and multicultural. Therefore, there should be a progressive creations to transform a religiousness worship valuesas a set of humanity social values.

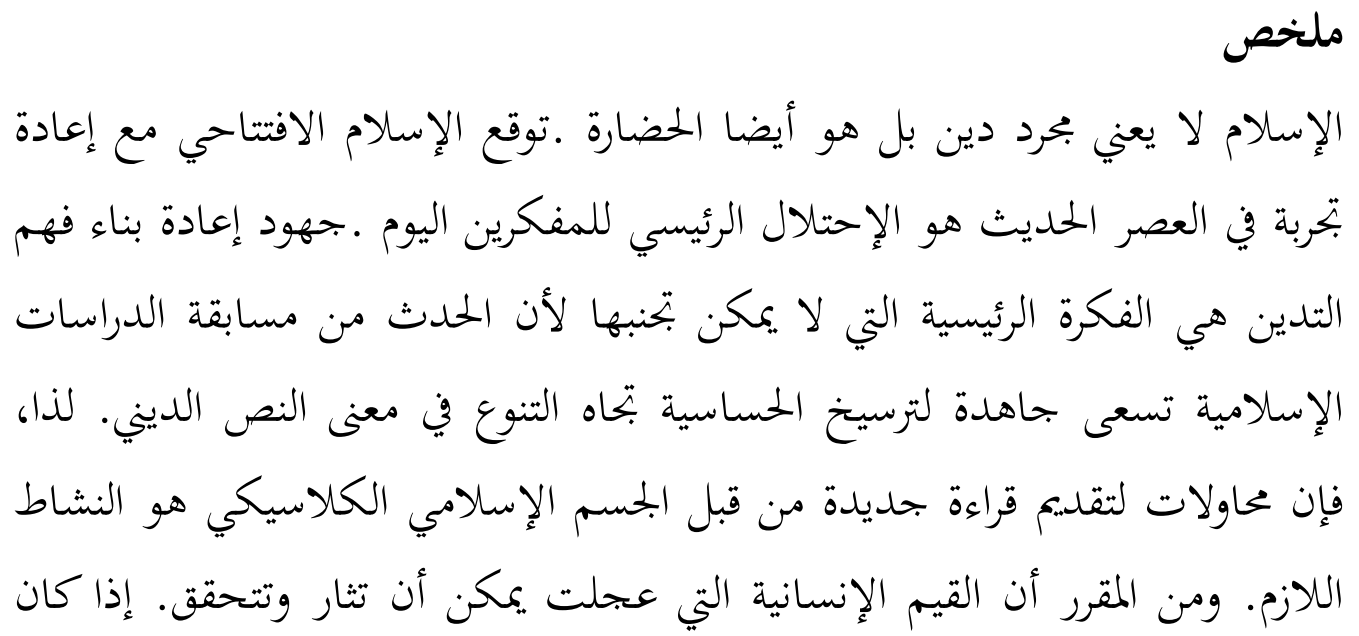




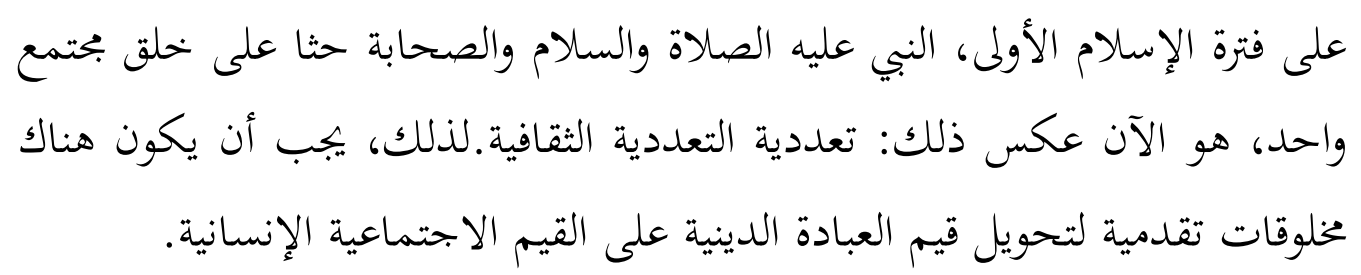

Keyword: Studi Islam, hukum \& etik, dan hak asasi manusia \& masyarakat sipil.

\section{A. Pendahuluan}

Sepanjang sejarah peradaban manusia, tampak jelas bahwa zaman ini adalah periode kehidupan yang kerapkali mengobrak-abrik sebuah tatanan yang dianggap sudah mapan, bahkan mempertanyakan kembali identitas semua pihak. Akibatnya, konsep tentang the other (yang lain: orang lain, agama/ bangsa/budaya lain) tidak diperkanankan untuk diacuhkan begitu saja. Maka secara otomatis citra diri dan jati diri manusia pun perlu dipikirkan bahkan juga dirumuskan.

Dua bidang kajian yang menempati posisi paling urgen sekaligus krusial di ambang milenium ketiga ini adalah etika dan manusia atau dalam spektrum yang lebih luas antara agama dan realita. Nilai urgensinya, sebab di atas keduanyalah kualitas wilayah peradaban manusia itu bertumpu. Sementara sisi krusialnya, karena kedua bidang tersebut kini sedang menghadapi berbagai tantangan baru yang membuat keduanya terpaksa mengkaji ulang segala bentuk struktur dasar dalam bingkai-bingkai konseptualnya. Sebuah tantangan yang memperlihatkan bahwa berbagai kategori yang selama ini digunakan untuk memahami nilai-nilai kemanusiaan boleh jadi tidak lagi memadai, bahkan perlu direvisi kembali.

Situasi dilematis yang dihadapi oleh agama dan realita kini tak lagi bisa dilihat hanya sekadar sebagai problem kasuistik, melainkan menggugat jauh ke pondasi-pondasi yang paling prinsipil dari keduanya, alias lebih bersifat paradigmatik. Dengan demikian, jika keduanya gagal dipahami sebagai sebuah entitas yang saling menyempurnakan kesejahteraan manusia, maka hal terburuk yang akan terjadi adalah manusia terpaksa harus menyaksikan proses kelahiran sebuah persepsi yang kelak akan menyatakan bahwa agama dan realita sama-sama memiliki kecacatan. 
Dimensi lain yang juga kerapkali hadir menghantui kehidupan manusia modern -dalam spektrum agama dan realita- adalah bidang kehukuman yang turut andil menentukan hak-hak asasi manusia. Guratan wajah hukum yang semakin kehilangan nilai-nilai universalnya, menjadi masalah tersendiri yang menuntut untuk segera diselesaikan. Hukum yang pada awalnya bertugas mengawal gerak-laju kemanusiaan, kini justru nampak liar mengebiri nilainilai kemanusiaan.

Sebagai 'sang pemakna agama dan realita', tak ayal jika manusia pada akhirnya akan mengalami amnesia primordial kala dihadapkan dengan eksistensinya. Nilai-nilai etis yang hadir dari dalam dirinya, terkesan saling bertentangan, tidak sebagaimana mestinya. Apa yang nampak secara natural, justru terbaca tak masuk akal. Manusia yang terlahir lugu, terpaksa harus gagu ketika berupaya menyikapi apa yang sedang ia hadapi. Akibatnya, kebenaran tidak lagi mendakwa baik dan buruk, justru ia akan menjadi tersangka dalam setiap kasus kemanusiaan yang ada.

Bagaimana agama dengan segala kesuciannya yang sakral dapat dipahami oleh manusia secara netral? Seperti apakah dialektika relasional antara hukum dan etika dalam kacamata filsafat dan syari'at? Upaya apakah yang ditawarkan oleh agama dalam menciptakan konstruksi ideal masyarakat sipil? Serta bagaimanakah memberlakukan hak-hak asasi manusia yang muncul sebagai sebuah ide atau gagasan yang mencitakan tatanan nilai secara global dan universal?

Berangkat dari sekilas abstraksi permasalahan di atas, sebagai entitas ilmiah, maka Studi Islam berkewajiban untuk memberikan solusi demi menjawab segala macam bentuk problematika yang nampak jelas di hadapan manusia. Karena pada dasarnya, segenap problema tersebut merupakan permasalahan manusia dengan nilai-nilai kemanusiaannya sendiri. Artinya, pada akhirnya nanti manusialah yang akan menentukan posisi keberagamaannya dalam realita sosial kemanusiaannya.

\section{B. Prototipe Studi Islam; dari Teosentris ke Antroposentris}

Peristiwa jatuhnya Adam-Hawa dari taman Firdaus ke muka bumi tentu tidak akan pernah kita lupakan begitu saja. Karena dari peristiwa itulah, umat manusia memasuki alam semesta tanda tanya. Semua yang ada di jagad raya 
ini seolah menjelma menjadi pertanyaan-pertanyaan yang hingga sampai detik ini, tidak pernah berhenti. A pakah sebenarnya kodrat alam semesta? Mengapa manusia ada? Bagaimanakan proses penciptaanya dan di manakah posisi kosmiknya? Bahkan sampai sejauh manakah tujuan eksistensialnya?

Pada zaman kontemporer yang semuanya seakan serba terbalik dan moratmarit -yang baik terlihat buruk pun sebaliknya- seharusnya kebenaran agama tidak dikaburkan di balik parade ritus, juga tidak dibatasi oleh nilainilai tampilan luar. Salah satu penyakit teoretis dalam dunia Islam, pada umumnya, adalah bahwa orang lebih memahami Islam hanya sebagai identitas daripada sebagai kebenaran. Jadi, seharusnya entitas agama setiap manusia adalah pemahamannya tentang kebenaran agama, sebagaimana juga setiap ilmu pengetahuan manusia adalah pemahamannya tentang kebenaran alam semesta. Kiranya problematika itulah yang hendak diketengahkan sebagai titik sentral kajian. Dengan demikian, asa mulia dari kajian ini adalah penegasan sekaligus pematenan status bahwa Studi Islam membutuhkan kompas baru untuk menemukan jalan damai antara agama dan realita guna menyibak ruang baca teks keagamaan dengan realita sosial kemanusiaan.

Mendefinisikan agama, dalam hal ini Islam, secara global dan utuh tentu tidak semudah dengan hanya menyatakan bahwa Islam adalah dogma yang mengajarkan tentang katauhidan semata. Karena memang pada kenyataannya Islam lebih dari itu. Paling tidak Islam memiliki dua tipologi eksistensial; di satu sisi ia adalah agama (religion), yakni sebuah sistem kepercayaan dan peribadatan; dan di sisi yang lain ia adalah sebuah peradaban (civilization), yang mana selalu tumbuh dan berkembang di bawah nuansa dan pengawasan agama itu sendiri. ${ }^{1}$

Sedari eksistensi awalnya, tentu keberadaan agama diyakini menjadi salah satu bukti agar manusia mengenal dan memahami kebenaran yang hakiki. Kebenaran dalam agama tentu tidak hanya memuat tentang kebenaran teologis semata, namun juga mengenai kebenaran etis, bahkan sampai pada kebenaran praksis. Klasifikasi kebenaran ini tentu merupakan hasil interpretasi manusia terhadap agama itu sendiri. Agama, yang saat ini diwakili oleh teks wahyu,

1 Carl W. Ernst, Following Muhammad, Rethinking Islam in The Contemporary World, (Capel Hill-London: The University of North Carolina Press,2003), hal. 57. Lihat dan bandingkan: Bernard Lewis, The Crisis of Islam, (New York: Random House, 2004), hal. 3. 
telah dengan tegas menjadikan manusia sebagai titik sasaran yang senantiasa menjadi bidikan utamanya. ${ }^{2}$

Berdasarkan dari dua tipologi definisi Islam di atas, status kebenaran yang akan lahir dari rahim agama akan senantiasa memiliki corak yang berbeda. Ketika Islam didefinisikan sebagai sebuah agama transenden yang berasal dari Dzat Agung, maka nilai kebenarannya pun harus mutlak dan absolut. Tidak akan pernah ada kebenaran yang paling benar kecuali kebenaran Dzat Agung itu sendiri. Tentu hal ini akan berbeda jika dibenturkan dengan nilai kebenaran ala filsafat. Filsafat melihat bahwa tidak ada kebutuhan yang lebih suci daripada kebutuhan akan sebuah kebenaran. ${ }^{3}$ Sebab tidak ada yang lebih berharga bagi para pencari kebenaran kecuali kebenaran itu sendiri. ${ }^{4}$

Sementara ketika Islam didefinisikan sebagai sebuah peradaban, maka nilai kebenarannya pun mengikuti sifat-sifat alamiah peradaban itu sendiri. Artinya, tekstur kebenaran di sini merupakan pendaran dari nilai-nilai peradaban. Peradaban dan tradisi sebuah masyarakat majmuk tentu tidak bisa dipaksakan untuk diterapkan pada masyarakat yang memiliki peradaban dan tradisi yang berbeda. Kalau pun bisa, tentu tidak dalam bentuk praktikalnya, melainkan pada nilai-nilai esensialnya. Kerena masing-masing masyarakat memiliki latar belakang sejarah yang berbeda-beda. ${ }^{5}$ Dari definisi Islam sebagai peradaban inilah manusia mengenal pengetahuan/ilmu-ilmu agama.

Peradaban dan tradisi sebuah masyarakat majmuk tentu tidak bisa dipaksakan untuk diterapkan pada masyarakat yang memiliki peradaban dan tradisi yang berbeda. Kalau pun bisa, tentu tidak dalam bentuk praktikalnya, melainkan pada nilai-nilai esensialnya. Kerena masing-masing masyarakat memiliki latar belakang sejarah yang berbeda-beda. ${ }^{6}$ Sementara agama, selama ini terbukti dapat melindungi sekaligus melegitimasi keberadaan manusia yang berbeda-beda, dengan tetap mampu menancapkan nilai-nilai esensial ajarannya.

2 Muhammad Bin Idris Al-Syafi'i, Al-Risâlah, (Kairo: Maktab Dar Al-Turats, 2005), cet. II, hal. 111-112.

3 Raimond Gaita, A Common Humanity: Thinking about Love and Truth and Justice, (London: Routledge, 2002), hal. 189.

4 Majid Fakhry, A History of Islamic Philosophy, (New York: Columbia University Press, 1983), cet. II, hal. 71.

5 Hasan Hanafi, Dirâsât Falsafiyah, (Kairo: Maktabah Al-Angelo Al-Masriyah, tt.), cet. I, hal. 135.

6 Ibid.,hal. 135. 
Dengan demikian, atas pola dasar inilah muncul terma kemanusiaan. ${ }^{7}$

Berangkat dari status wahyu yang terbaca (al-nash al-maqrû'), agama -melalui bahasa teks wahyu- seolah memberikan dimensi pemahaman baru bagi kebenaran. Hanya saja, patut dipahami dan digarisbawahi bahwa dimensi tersebut akan senantiasa terikat dengan ruang dan waktu, dimana manusia sebagai subjek yang mempraktikkan agama (beragama) merupakan makhluk Tuhan yang sedari eksistensi awalnya sudah tak sama. Sebelum melangkah lebih jauh, ada baiknya jika kita menjelaskan bahwa terma "agama" tentu berbeda dengan terma "beragama". Jika kebenaran agama bersifat tunggal, mutlak dan absolut karena ia berasal dari Tuhan, sebagaimana yang sudah disampaikan di atas, maka kebenaran beragama akan bersifat sebaliknya. Ini tidak terlepas karena kebenaran beragama merupakan hasil interpretasi manusia tehadap teksteks agama. Oleh karena itu, berdasarkan keberadaan manusia yang majmuk dan berbeda, maka kebenaran beragama harus bersifat plural dan multidimensional.

Sebagai makhluk yang memiliki sifat kemanusiaan, maka sudah sewajarnya manusia juga memiliki hak-hak asasinya, termasuk hak asasi dalam memahami dan mengetahui objek-objek tertentu. Jika dalam agama hak melegalkan kebenaran itu hanya bersumber dari Tuhan, maka pada manusia tentu harus melalui proses pencarian terlebih dahulu. Berangkat dari eksistensinya yang tak sama, manusia dalam upaya mencari dan menemukan kebenaran pun tentu juga akan berbeda. ${ }^{8}$

Kant pun beranggapan bahwa manusia menduduki wilayah ciptaan yang istimewa. Memang dia bukan satu-satunya yang beranggapan demikian. Gagasan ini sudah tua usianya. Sejak zaman kuno, manusia menganggap dirinya secara hakiki berbeda dengan makhluk ciptaan yang lainnya, dan bukan hanya berbeda, melainkan yang terbaik. Dalam kenyataannya, manusia secara tradisional dirinya sebagai yang menakjubkan. Bagi Kant, manusia memiliki nilai intrinsik yakni martabat, yang membuatnya bernilai mengatasi segala harga. ${ }^{9}$

7 Jack Donnely, Universal Human Rights in Theory and Practise, (London: Cornell University press, 2003), cet. II, hal. 72. Lihat dan bandingkan: James Forsyth, Psycological Theories of Religion, (New Jersey: Prentice Hall, 2003), hal. 136.

8 Elmer Sprague, Knowledge and Value, (New York: Harcourt-Brage\& World, 1976), cet. II, hal. 328.

9 James Rachels, The Elements of Moral Philosophy, diterjemahkan Filsafat Moral (Yogyakarta: Kanisius, 2003), cet. VI, hal. 234. 
Dalam perspektif pencarian kebjiksanaan beragama, kegiatan manusia dalam proses mengetahui agama merupakan bagian yang tak terpisahkan dari cara berada manusia (knowing is a mode of being). Perilaku ini merupakan sisi fundamental yang juga tidak bisa dipisahkan dari kegiatan manusia untuk hidup sebagai manusia. Pengetahuan beragama yang dikembangkan oleh manusia merupakan langkah positif agar ia dapat bertindak secara lebih tepat dalam interaksinya dengan dunia, masyarakat sekitar, dirinya sendiri, dan bagi orang beriman, tentu juga dengan Tuhan (knowledge is for the sake of action). Sebuah penegasan yang tidak bisa kita kesampingkan dan harus kita tetapkan. Oleh sebab itu, kompas baru Studi Islam harus mampu membingkai tekstur kesaling-terkaitan antar semua dimensi dalam prototipe dialektika agama dan realita yang senantiasa menghubungkan hukum dan etika, juga hak asasi manusia guna merealisasikan masyarakat sipil yang ideal dan paripurna.

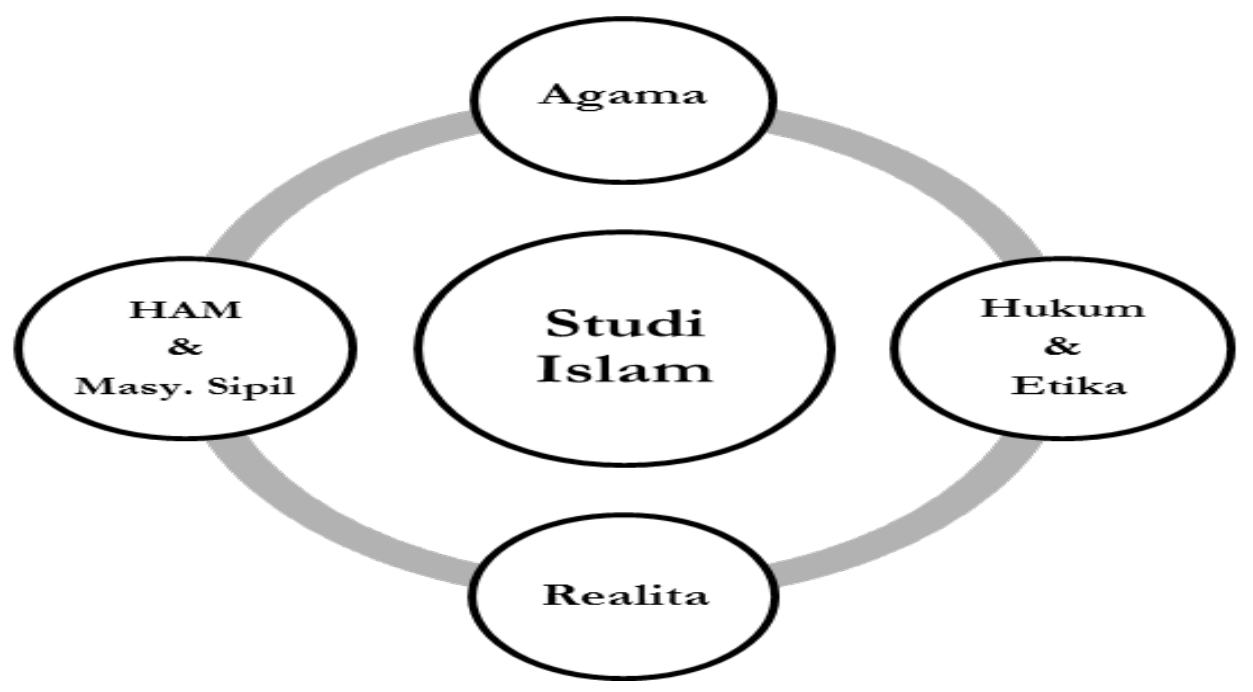

Relasi antara agama dan manusia dalam realita merupakan sebentuk ikatan yang mampu membidani lahirnya sebuah nilai dalam tatanan kemasyarakatan. Agama yang hadir membawa pesan moral akan senantiasa mengawal geraklaju manusia dalam menjalani kehidupan. Kebebasan berkehendak (free will) yang dianugerahkan sapaket tatkala manusia lahir merupakan acuan interaksi sosial-keagamaan. Sebab agama, melalui berbagai macam media, berjanji membimbing kehendak tersebut agar tidak keluar dari garis-garis besar kemaslahatan (straight path). 
Keyakinan beragama yang diejawantahkan dalam praktik keagamaan merupakan seperangkat nilai yang disarikan dari prinsip hirarki keimanan dan keislaman (arkân al-imân dan arkân al-islâm). Relasi ganda kedua konsep tersebut dengan manusia mengindahkan pencapaian hubungan yang paripurna: vertikal dan horizontal.

Pemahaman keagamaan merupakan sebentuk laku kesadaran manusia dalam beragama. Cara manusia memahami agama senantiasa akan mengalami hambatan jika ia tidak mampu menangkap pesan-pesan Tuhan (al-murâd alilâhiy) yang tersirat dalam setiap sendi ajaran agama. Ramadhan sedari eksistensi awalnya telah diyakini sebagai periode fase yang penuh dengan keberkahan. Aktifitas keagamaan tentu tidak hanya dipahami sebatas menumpuk pahalapahala ritual peribadatan, namun juga harus mampu memupuk kepekaan terhadap nilai-nilai kemanusian (human values).

\section{Hukum dan Etika; Dialektika Filsafat dan Syari'at}

Interpretasi makna hukum dalam perspektif falsafati pada awalnya terlepas dari rumusan-rumusan konstitusional. Menurut Aristoteles, jika sebuah hukum tidak memiliki daya perintah, maka konstitusi tidak akan pernah ada. ${ }^{10}$ Sebab hukum hadir sebagai sebuah gagasan yang dirumuskan untuk menjadi rangkaian nilai yang menata kehidupan. Di sini, hukum harus membela siapa saja yang dilanggar hak-haknya. ${ }^{11}$ Itu artinya hukum diposisikan sebagai kebenaran alami/sifat sebenarnya sebuah perwujudan(law as the true nature of appearance). Karena perwujudan/apa yang tampak tidaklah hanya merupakan tentang dunia logika-pengetahuan dan persepsi yang bersifat positivis semata, melainkan juga sebagai pengganti sebuah kebenaran atas apa yang tak tampak (inner world). ${ }^{12}$ Fenomena-fenomena natural inilah yang dalam babakan selanjutnya menjelma menjadi aturan-aturan kehidupan. Pada titik inilah, Aristoteles menyatakan bahwa manusia adalah political animal. Dengan demikian, ketika komunitas manusia berada dalam kondisi natural yang baik,

${ }^{10}$ Fred D. Miller, Jr., Nature, Justice and Rights in Aristotle's Politics, (New York: Oxford University Press, 1995), cet. I,hal. 82.

11 Ibid., hal. 79

12 G. W. F. Hegel, The Phenomenology of Mind, (New York: Dover Publicationm, 2003), cet. I, hal. 83. 
maka sejatinya mereka sedang berada dalam naungan nuansa keadilan. ${ }^{13}$

Sebelum hukum terejawantahkan dalam praktik-praktik laku sosial, pada dasarnya ia merupakan sebentuk ide yang memiliki tujuan untuk menciptakan keharmonisan dalam tatanan kehidupan. Kehidupan di sini tidaklah bersifat tunggal, melainkan harus bersifat universal. Artinya, ada nilai yang ingin diposisikan sebagai gagasan utama teori keadilan (the main idea of theory of justice). Gagasan inilah yang kemudian menjelma menjadi prinsip-prinsip keadilan sebagai basis struktur kemasyarakatan yang mana ia merupakan sebentuk objek orisinal sebuah kesepakatan. ${ }^{14}$

Aristoteles mengklasifikasikan konteks keadilan menjadi empat model; pertama, keadilan universal (universal justice). Hukum harus dibentuk dengan berlandaskan pada keadilan, dan ia diarahkan sebagai pedoman bagi perilaku individu-individu dalam keseluruhan hal yang bersinggungan dengan konteks kehidupan bermasyarakat. Proses pembentukan itu dengan demikian, bertitikberat pada atau melingkupi keseluruhan tema yang berhubungan dengan masyarakat. Kedua, keadilan partikular (particular justice) adalah bagian dari keadilan universal. Kedua tipe keadilan ini, baik universal maupun partikular, sama-sama memperhatikan manusia asalkan mereka memiliki tujuan umum yang sama atau dalam bentuk sebuah komunitas. Keadilan universal mencakup segala macam bentuk kebajikan etis, selama ia mempromosikan dan melindungi kebaikan dalam masyarakat. Sedangkan keadilan partikular lebih menekankan tindakan-tindakan yang dapatmempengaruhi kepentinganumum. Masih dalam konteks keadilan, selanjutnya Aristoteles melengkapi dua jenis keadilan di atas dengan dua konsep tambahan, yakni keadilan legal/menurut hukum (legal justice) dan keadilan natural/menurut alam (natural justice). Sebuah pemisahan yang dapat kita sederhanakan menjadi keadilan berdasarkan hukum positif dan keadilan dalam perseptual hukum alam. Konsep ini merupakan salah satu tema sentral dalam keseluruhan filsafat hukum alam. ${ }^{15}$

Berbeda dengan Aristoteles, menurut Immanuel Kant, hukum merupakan bagian dari gejala-gejala obyek pengetahuan. Oleh sebab itu, hukum termasuk ke dalam kategori bidang pengetahuan praktis karena sebagai realitas

\footnotetext{
13 Fred D. Miller, Jr., op. cit.,hal. 81.

14 Jhon Rawls, A Theory of Justice, (USA: Havard University Press, 1971), hal. 11.

15 Ibid., hal. 68-78.
} 
objektif. ${ }^{16}$ Bidang pengetahuan praktis ialah bidang kehidupan manusia, yakni sebuah fenomena dimana manusia bertindak. Bidang ini ditandai dengan istilah harus (sollen), sebab hidup dialami manusia sebagai suatu kehidupan di bawah kewajiban. ${ }^{17}$ Artinya, manusia yang merasa paling bebas sekalipun akan tetap menyadari bahwa sebenarnya ada batas-batas tertentu yang tidak boleh dilakukannya. Dengan demikian, sudah seharusnya manusia dalam bertingkahlaku menuruti prinsip-prinsip tertentu. Prinsip-prinsip lelaku manusia disebut sebagai norma-norma moral.

Pengukuhan etika murni sebagai nilai kewajiban dalam berhukum ${ }^{18}$ merupakan salah satu ide besar Kant. Menurutnya, sebuah sistem hukum dapat dikatakan benar jika dalam langkah-langkah pengambilan keputusannya senantiasa terlebih dahulu memperhatikan nilai-nilai moral. Ia menegaskan bahwa meskipun politik sendiri merupakan seni berhukum yang sulit, tapi ia senantiasa harus tetap dikombinasikan dengan moralitas. Pada titikini, hak-hak manusia harus dianggap suci. Dengan demikian, semua kegiatan berhukum harus bertekuk lutut di hadapan mimbar kebenaran. ${ }^{19}$

Pada dasarnya sebagaimana alam, hukum tidak diam. Ia senantiasa mengalami perkembangan, tidak hanya dalam isinya, melainkan juga pada teksturnya. Dengan demikian, nuansa-nuansa keadilan yang awalnya bersifat natural -setelah disadari oleh manusia- maka pada segmen selanjutnya ia akan menjelma menjadi sistem-sistem peradilan yang institusional-konstitusional. Dimana sistem-sistem peradilan tersebut harus menjadikan moralitas sebagai nilai wajib setiap keputusan hukum. Oleh karena itu, manusia yang pada awalnya diposisikan oleh Aristoteles sebagai 'political animal' dengan menjadikan hukum alam (law of nature) sebagai prinsip keadilan akan melahirkan satu gagasan pengetahuan tentang sifat/tabiat manusia (human nature). Sementara sistem peradilan yang menggunakan hukum etik (law of ethic) melalui filsafat moral ala Immanuel Kant, akan menuntun manusia untuk memahami satu

16 Immanuel Kant, Critique of Practical Reason, (USA: The Liberal Arts Press, 1956), hal. 15.

17 Emile Boutroux, La Philosohie De Kant, dialihbahasakan Falsafatu Kant oleh Usman Amin, (Kairo: Al-Haiah Al-Mashriyah Al-Amah, 1971), hal. 12.

18 Immanuel Kant, The Moral Law (Groundwork of The Metaphysic of Morals), (London: Routledge, 2005), hal.56.

19 Immanuel Kant, Perpetual Peace, dalam buku Philosophy and Revolution from Kant to Marx oleh Stathis Kouvelakis, (New York: Verso,2003), cet. I, hal. 17. 
gagasan baru tentang hak-hak asasi manusia (human rights). Dua gagasan inilah yang pada akhirnya nanti akan saling menyempurnakan setiap aspek hukum.

Jika etika dalam filsafat terlahir dari pengamatan-pengamatan natural dan rasa kemanusiaan (sense of humanity), maka etika dalam perspektif agama hadir dengan perwajahan yang berbeda. Para pemikir Arab-Islam sendiri telah bersepakat bahwa sifat tidak terpuji merupakan penyakit diri yang harus diobati. Hanya saja mereka berselisih pada ruang-ruang metafisik moralitasnya. Sebagian dari mereka meyakini bahwa etika merupakan asupan nilai dalam diri setiap manusia. Sementara sebagian yang lainnya menyatakan bahwa etika merupakan sebentuk hal terberi dalam diri setiap manusia yang suci, tetap dan tidak berubah. ${ }^{20}$ Sebenarnya kita dapat mengkritisi hal tersebut dengan mengharmonisasikan keduanya seraya menyatakan bahwa memang dalam diri setiap insan terdapat nilai-nilai keluhuran.

Tidak seperti halnya etika dalam filsafat yang hadir dari pengamatan manusia terhadap nilai alamiah dan nilai kemanusiaannya sendiri, etika dalam agama memiliki tekstur wajah yang berbeda. Pada ranah filsafat logika dengan tegas menyatakan bahwa akal budi murni sekaligus praktiknya merupakan dua hal yang paling berhak untuk mengkonsepkan etika. Sementara hal apakah yang paling berhak menentukan etika dalam perspektif agama, apakah akal (al'aql) atau teks agama (al-naql), hingga kini masih menjadi polemik tersendiri bagi para pakar praktisi hukum agama.

Hukum dalam tradisi keilmuan Islam merupakan relasi ganda yang senantiasa menghubungkan antara manusia dengan Tuhannya (theocentric relationship) dan juga antar sesama manusia (anthropocentric relationship). Dari kedua relasi inilah, hukum dalam periode Islam klasik memiliki empat model keberpihakan; hak-hak Tuhan (the rights of God), hak-hak manusia (the rights of human beings) ${ }^{21}$, hak antar keduanya namun hak Tuhan lebih tinggi (God's rights is higher than human's), dan hak antar keduanya namun hak manusia lebih tinggi (human's right is higher than God's). ${ }^{22}$

20 Taufiq Al-Thawil, Falsafah al-Akhlâq Nasy'atuhâ wa Tathawaruhâ, (Kairo: Dar AlTsaqafah, tt), cet. IV, hal. 160 .

21 Abdullahi Ahmed An-Na'im, Toward an Islamic Reformation, Civil Liberties, Human Rights and International Law, (Kairo: American University, 1992), hal. 5.

${ }^{22}$ Wahbah Zuhailiy, Ushul al-Figh al-Islâmiy, (Beirut: Dar el-Fikr, 1986), cet. I, hal. 153156. 
Berangkat dari keempat model tersebut, jika kita cermati lebih teliti, hukum dalam perspektif Islam tidak hanya melulu tentang aturan-aturan Tuhan yang sepenuhnya hanya bersifat doktrinal dan sarat akan dogma. Namun sejatinya hukum Islam senantiasa memberikan ruang dan peluang kepada manusia dalam upayanya mengimplementasikan hukum, baik secara individual maupun sebagai masyarakat komunal.

Membincang asal-usul etika dalam perspektif agama, lagi-lagi kita akan dihadapkan kepada peristiwa klasik dalam proses pemaknaan hukum dari segi akidah, khususnya yang berkaitan dengan ihwal baik dan buruk. Problematika baik dan buruk dalam perjalanan interpretasi teks-teks keagamaan selalu saja hadir dengan dua perwajahan berbeda. Hal tersebut menjadi wajar dan dapat dimaklumi mengingat status akal dan teks-teks agama merupakan bagian kesatuan hidup manusia beragama yang bias dibedakan namun tak dapat dipisahkan. Apakah manusia beragama karena ia berakal, atau sebaliknya, apakah ia berakal karena beragama. Lalu apakah etika hadir dari rahim akal ataukah ia lahir berkat bimbingan wahyu, merupakan peristiwa lanjutan dari kasus sebelumnya.

Sekte Muktazilah dengan mantap menegaskan bahwa proses penghakiman sesuatu menjadi sebuah etika tidak lain adalah dengan menggunakan akal manusia. Evidensi yang kerapkali digunakan sebagai argumentasi adalah bahwa dakwaan akal terhadap sesuatu itu baik atau buruk merupakan kesadaran terberi. Ini artinya bahwa akal manusia telah mampu membedakan baik dan buruknya sebuah perkara, bahkan sebelum risalah kenabian itu turun ke daratan muka bumi ini (al-'aql qabla wurûd al-sam'i). Dalam hal ini, perspektif sekte Muktazilah sama persis dengan cara pandang filsafat ketika memposisikan logika sebagai sumber etika hukum. ${ }^{23}$

Berbeda dengan Muktazilah, Ahlu Sunah justru menggunakan logika terbalik. Status akal manusia tidak lagi menjadi sumber etika, melainkan hanya sebagai media. Ini artinya bahwa memang benar akal dapat mengetahui mana yang baik atau yang buruk, namun keputusan hukum sesuatu itu baik atau buruk hanyalah bersumberkan dari teks-teks agama. ${ }^{24}$ Dengan tegas Imam Al-

${ }^{23}$ Muhammad Abid Al-Jabiri, Arab Ethical Reason (al-'Aql al-Akhlâqiy al-'Arabiy), (Beirut: Markaz Dirasat Al-Wahdah Al-Arabiah, 2011), cet. IV, hal. 113.

${ }^{24}$ Ibid., hal. 116. 
Ghazali menyatakan bahwa baik-buruknya sebuah perbuatan tidaklah dapat diketahui melalui penalaran. Sebab cara terbaik untuk mengetahui baik-buruknya perbuatan manusia adalah dengan pedoman-pedoman teks keagamaan. ${ }^{25}$

Sengketa antara Muktazilah dan Ahlu Sunah mengenai problematika sumber etika, seharusnya bisa diselesaikan dengan logika secara sederhana. Kita dapat mengkritisi masalah ini dengan memberikan proposisi bahwa sejatinya bingkai konseptual dalam filsafat hukum Islam -mengenai keetikaanselalu saja menghadirkan dua wajah yang sama-sama saling membutuhkan antara satu dengan yang lainnya; penalaran murni teks (naqliyun mahdun) dan penalaran murni konteks ('aqliyun mahldun). ${ }^{26}$

Kedua proposisi di atas dapat kita jadikan sebagai struktrur hipotesa untuk menyatakan bahwa teks (al-naq'l) adalah sebuah tesa dan konteks (al-wâqi') sebagai antitesanya, serta akal (al-'aql) sebagai sintesa dari keduanya. Sebab ketiganya tak akan pernah dapat dipisahkan. ${ }^{27}$ Terlebih karena manusia yang berakal merupakan sasaran inti wahyu, dimana ia selalu membutuhkan ruang dan waktu sebagai tempat hidupnya. Dengan demikian, dapat kita simpulkan bahwa tekstur kebenaran sumber etika dalam perspektif agama merupakan hasil dari perpaduan antara teks agama, konteks dan akal manusia.

Dari dua model interpretasi makna hukum dan etika yang telah dipaparkan, jika kita cermati lebih teliti, maka kita akan mendapati bahwa titik pertemuan antara filsafat hukum dan studi hukum dalam konteks Islamic Studies adalah kesamaan dalam menerima suatu hukum sebagai hukum yang benar (accept an law as true law). ${ }^{28}$ Di sini kita tidak sedang menundukkan satu tekstur kebenaran dengan tekstur kebenaran yang lainnya, melainkan kita sedang berupaya untuk melakukan inter-epistema antara syari'at dan filsafat dalam ranah hukum. Pada titik inilah kebenaran relasional (relational truth) itu lahir. Karena syari'at tidak akan pernah alpa dari etika, begitu juga dengan filsafat, maka posisi etika yang netral dapat dijadikan sebagai formula epistemologi baru dalam berhukum.

25 Abu Hamid Al-Ghazali, al-Mankhûl min Ta'lị̂ât al-Ushûl, (Beirut: Maktabah 'Ashriyah, 2008), cet. I, hal. 15.

26 Abu Hamid Al-Ghazali, al-Mustashfa min 'Ilmi al-Ushûl, (Beirut: Dar An Nafa'es, 2011), cet. I, Vol. I, hal. 98.

27 Hasan Hanafi, min al-Nash ilâ al-Wâqi', (Kairo: Markaz Al-Kitab, 2005), cet. I, Vol. II, hal. 46.

${ }^{28}$ Herman Bakir, Filsafat Hukum: Desain dan Arsitektur Kesejarahan, (Bandung: Refika Aditama, 2009), cet. II, hal. 219. 
Bagi para pemeluk agama Islam, hukum agama atau syari'ah merupakan segenap kewajiban umat manusia (whole duty of mankind). Ia tidak semata-mata hanya mengatur urusan kelangitan, atau hanya sekadar menjadi aspirasi untuk mencapai tingkat spiritual yang tinggi, atau sekadar rincian ritual dalam nalar formal ketaan; tetapi syari'ah juga senantiasa mencakup semua aspek hukum publik dan swasta, bahkan juga tentang kebersihan dan kesopanan serta tata cara praktik kebaikan.

Untuk dapat memberikan hukum yang universal sebagai rahmat untuk semua manusia, selayaknya syari' ah harus mampu menaungi segenap manusia di alam jagad raya ini. Maka langkah selanjutnya adalah melakukan reformasi bingkai konseptual syari'ah dari yang awalnya hukum agama (law of religion) menjadi hukum publik (law of public). Sebuah cita-cita yang cukup sensasional di awal abad milenium ketiga ini.

Para praktisi hukum syariah di era awal tidaklah mengenal perbedaan jenis-jenis hukum yang bergenre publik dan konstitusional .Seperti yang telah dijelaskan dalam berbagai literatur teks hukum, perbedaan yang dibuat oleh para ahli hukum Islam awal adalah antara hak-hak Dzat Agung dan hak-hak manusia, ${ }^{29}$ tidak ada hubungannya dengan perbedaan antara hukum publik dan swasta.

Tetapi perlu disadari terlebih dahulu bahwa meskipun para praktisi hukum di era awal tidak menggunakan terma hukum publik, sejatinya mereka telah berhasil memberikan serpihan-serpihan embrio hukum universal yang dapat dilaksanakan dalam sebuah Negara. Sebab dalam putusan-putusan hukumnya, sejatinya telah terbukti memberikan pengaruh positif terhadap kehidupan setiap manusia, baik secara pribadi maupun secara kolektif. Sehingga memungkinkan kita untuk mengambil nilai-nilai etika hukum yang melibatkan hukum publik dalam pengertian istilah modern dan mencari prinsip yang sesuai dalam aturan main syari'ah. Berdasarkan tesis tersebut, maka kemudian kita akan dapat menyatakan bahwa prinsip-prinsip syari'ah sejatinya memang masih relevan dan menilai penerapannya sebagai hukum publik modern. ${ }^{30}$

29 Sa'duddin Bin Umar Al-Taftazaniy, Syarh al-Talwîh 'ala Taudîh, (Beirut: Al-Maktabah Al-'Ashriyaah, 2005), cet. I, Vol. II, hal. 319-329.

30 Abudllahi Ahmed An-Na'im, op . cit.,hal. 9. 


\section{Agama dan Negara; dari HAM ke Konstruksi Ideal Masyarakat Sipil}

Selama ribuan tahun pertama dari sejarahnya, hubungan Islam dan Kristen merupakan hubungan yang paling dominan. Lepasnya Spanyol dan Portugis ke tangan kekuasaan Barat sangat sedikit pengaruhnya terhadap pusat kekuasaan Islam dibandingkan kerugian yang diterima dengan kemajuan benua Eropa. Pada akhir 1683, angkatan perang Usmaniyah menetap di depan pintu gerbang Vienna. Di awal abad 19, kekuasaan Islam berada dalam keadaan mundur saat kekuasan Eropa justru bangkit. Menyadari bahwa mereka menjadi tujuan utama dari penjajahan, umat Islam secara alami ingin mengetahui kesalahan apa yang telah terjadi. Berbeda dengan pendiri Kristen yang disalib dan pengikutnya menyaksikan agama mereka secara resmi diterima oleh kerajaan Romawi hanya setelah berabad-abad mereka menjadi umat minoritas yang diburu. Sementara Muhammad Saw. membentuk negara saat masih hidup dan menjadi penguasa, mengumpulkan pajak, melaksanakan pengadilan, membuat undang-undang, memimpin angkatan perang dan menetapkan keadaan perang atau damai.

Umat Islam yang terdidik merasa kecewa dengan kemampuan orang Eropa sebagai pesaing mereka. Mereka bertanya-tanya: "Semua yang mereka lakukan benar dan semua yang kita lakukan salah, atau sebenarnya kita tidak sedang melakukan apa-apa". Diskusi yang singkat mengenai masalah-masalah besar akan cenderung mudah tergiring pada kesalahan dalam menggunakan (misuse) atau kesalahan dalam menafsirkan (misinterpretation) beberapa kata yang digunakan. Oleh sebab itu, mendedah terma human rights dan civil society merupakan sebuah keniscayaan.

Human Rights atau yang dalam bahasa Indonesia diterjemahkan dengan hak asasi manusia merupakan gabungan kata yang memiliki makna tinggi. Di sini kita tidak hanya sedang membicarakan eksistensi manusia, namun juga membincang hak-hak asasinya sebagai manusia. Dalam hal ini, istilah hak asasi manusia mengacu pada hak-hak yang diakui oleh dan ditegakkan melalui hukum dan institusi-institusi internasional. Lalu masalahnya adalah apakah hukum mampu menghasilkan tatanan paripurna perihal human rights ini? Mampukah Islam, dengan syari'ahnya memproduksi human rights dalam memperjuangkan nilai-nilai kemanusian (human values)? Apakah Barat dengan kajian human rights-nya tidak memiliki kecacatan paradigmatik kala 
membincangnya sebagai acuan dasar yang universal? Kiranya inilah beberapa problem yang menarik untuk dikaji.

Jika kita cermati, kajian seputar human rights tidaklah melulu soal hukum, namun juga mengenai permasalahan ekonomi-sosial-budaya. Benar bahwa human rights diakui dan diputuskan berlaku jika ia telah naik ke meja hukum dan tercatat sebagai panduan dalam buku undang-undang dunia, namun benar juga bahwa meskipun ia membahas hak-hak asasi manusia, tidak semua manusia di muka bumi ini mengetahui keberadaannya. Dari sini, kita bisa menyimpulkan bahwa human rights dunia sejatinya belum tersalurkan secara komprehensif. Sebab latar belakang budaya sebuah masyarakat kerapkali berbeda dengan entitas masyrakat lain. Dengan demikian, upaya universalisasi human rights dengan sendirinya dalam beberapa titik akan mengalami kesulitan.

Pasal 1.3 piagam PBB, mewajibkan kerja sama bagi seluruh anggota PBB untuk mempromosikan dan memperjuangkan hak-hak asasi dan kebebasan bagi seluruh umat manusia, tanpa membedakan ras, jenis kelamin, bahasa maupun agama. Namun permasalahannya adalah lalu bagaiamana dengan negara-negara yang tidak ikut bergabung dengan PBB, atau menarik diri dari organisasi luar biasa tersebut? Nah, di sinilah seharusnya umat Islam mampu memberikan sumbangsih pengetahuan yang memadai. Tapi sayang, hingga saat ini kita belum menemukan satu buku utuh yang benar-benar membincang the ideal concept of Islamic human rigts.

Kesulitan utama membangun standar universal, yang melintasi batasbatas kultural, khususnya agama adalah bahwa masing-masing tradisi memiliki kerangka acuan (frame of reference) internalnya sendiri, karena masing-masing tradisi menjabarkan validitas ajaran dan norma-normanya dari sumber-sumbernya sendiri. Jika suatu tradisi kultural, khususnya agama, berhubungan dengan tradisi-tradisi yang lain, maka kemungkinan yang terjadi adalah hubungan secara negatif dan bahkan dengan cara permusuhan. Untuk mengklaim loyalitas dan kepatuhan anggota-anggotanya, suatu tradisi kultural atau agama secara normatif menegaskan kelebihan dirinya atas tradisi-tradisi yang selainnya. ${ }^{31}$

31 Para juru bicara resmi Republik Iran telah menyuarakan keyakinan mereka bahwa mereka dilandasi oleh hukum Islam dan bukan standar-standar hak-hak asasi manusia internasional. Lihat koleksi berbagai statemen tersebut dalam Edward Mortiner, 'Islam and Human Rights', (Index on Censorship 12, no. 5, 1983), hal. 5-6. 
Problem umum ini harus dibicarakan di dalam masing-masing tradisi kultural. Dalam kasus Islam, misalnya, seseorang harus dapat membangun suatu teknik penafsiran ulang atas sumber-sumber dasar, Al-Qur'an dan Sunah, dengan cara yang memungkinkan kita untuk menyingkirkan bentuk-bentuk diskriminasi terhadap perempuan dan non-Muslim. Barangkali inilah yang menarik hati Abdullah Ahmed An-Nai'm ketika membincang human rights dalam buku kontroversialnya; Toward an Islamic Reformation, Civil Liberties, Human Rights and International Law. ${ }^{32}$

Tanpa masuk ke detail-detail argumen yang mungkin terlalu dekat diidentifikasikan dengan tradisi kultural tertentu seorang pemikir dapat membuat pembenaran lintas-kultural dasar-dasar standar hak-hak asai manusia universal. Kriteria yang dapat kita jadikan acuan rujukannya meupakan identifikasi hak-hak asasi manusia adalah bahwa hak-hak tersebut diberikan karena kemanusiaannya. Dengan kata lain, standar hak-hak asasi manusia universal secara definitif diapresiasi oleh berbagai tradisi budaya yang luas karena menyangkut harkat dan kesejahteraan yang inheren pada setiap umat manusia.

Selama Islamic Studies belum mampu memetakan dengan baik dan mengkonsepkan dengan benar seperti apakah bentuk-bentuk the ideal concept of Islamic human rights, maka cita-cita untuk menjadi al-insân al-kâmil atau dalam bahasa Al-Qur'an sebagai khalifah muka bumi, hanya akan menjadi anganangan kosong yang terjebak dalam ruang limbo. Jika tidak, tranformasi umat Islam dari traditional society menuju civil society akan senantiasa mengalami stagnasi.

Sebagai starting point dalam mencari penyelesaian persoalan yang akan kita perbincangkan, Jabiri merangsang kita dengan terlebih dahulu harus mengemukakan pertanyaan ganda: Mungkinkah demokrasi tegak di tengah masyarakat yang tidak civilized (madani) dan mungkinkah civil society dapat ditegakkan di dalam sistem yang tidak demokratis? ${ }^{33}$

Kunci untuk memahami dan mengkaji seluk-beluk persoalan ini, adalah perhatian yang serius terhadap kandungan kalimat: perkembangan kondisi

32 Abudllah Ahmed An-Na'im, Toward an Islamic Reformation, Civil Liberties, Human Rights and International Law, (Kairo: The American University in Cairo Press, 1992).

${ }_{33}$ Muhammad Abid Al-Jabiri, Problem Demokrasi dan Civil Society, dalam Islam Liberalisme Demokrasi, (Jakarta: Paramadina, 2002), cet. I, hal. 232. 
secara historis dan alami menuju demokrasi modern. Karena demokrasi dan civil society -sebagai kedua entitas yang korelatif- adalah hasil dari perkembangan tersebut di mana kita semua mesti maklum bahwa tempat berproses perkembangan kondisi di Eropa dari sistem feodalisme kekuasaan menuju sistem kapitalisme liberal.

Istilah civil society muncul sebagai faktor penting yang berhubungan dengan demokratisasi di negara-negara berkembang, termasuk negara Timur Tengah dan Asia, khususnya negara-negara yang jumlah penduduk Muslimnya lebih banyak. Pada awalnya, terma civil society digunakan untuk memberi label pada kelompok-kelompok yang melawan negara, tanpa melihat tujuan atau karakternya. Keberadaan dan fungsi mereka bagaimana pun menghalangi hegemoni kekuasaan negara dan menambah prospek demokratisasi.

Penggunan konsep yang luas ini kadang-kadang menjadikan civil society tidak dapat dibedakan dari masyarakat secara keseluruhan. Lebih jauh, komponen-komponen civil society yang diduga menyebabkan atau berhubungan dengan munculnya demokrasi dibiarkan spekulatif. ${ }^{34}$ Terlebih beredar bagaimana negara mampu merusak prospek demokratisasi. Memang pengaruh negara terhadap masyarakat adalah penting, namun lebih penting lagi adalah pengaruh masyarakat terhadap negara. ${ }^{35}$

Terma civil society sekarang digunakan untuk menunjukkan bagaimana klub, organisasi, dan kelompok bertindak sebagai penyangga kekuasaan negara dan kehidupan negara. Dengan demikian, dalam ketiadaan asosiasi seperti itu, negara mendominasi urusan sosio-ekonomi dan swasta dengan mengintensifkan kecenderungan otoritarian negara. ${ }^{36}$

Civil society merupakan sebuah masyarakat yang hubungan antar anggotanya diatur di atas asas demokratis, yakni sebuah masyarakat yang mempraktekkan pemerintahan yang berdasarkan mayoritas politik kepartaian dan penghormatan terhadap hak-hak warga negara, baik hak-hak politik, sosial,

34 Untuk mengetahui pandangan singkat beragam pendekatan tentang Civil Society, lihat: Introduction, Theoritical Perspectives on Arab Liberalization and Democatization, dalam Rex Brinen, Bahgat Koraniy, dan Paul Noble, eds. Political Liberalization and Democratization in the Arab World: Theoritical Perspective, Vol.. I, Lynne Rienner, Boulder, 1995.

35 Ali R. Abootalebi, Democratization in Developing Countries: 1980-1989, Journal of Developing Areas 29, 1995.

${ }^{36}$ Mengenai latar belakang singkat Civil Society, lihat Ernest Gellner, Civil Society in Historical Context, (International Social Science Journal, Agustus 1991), hal. 495-510. 
ekonomi dan budaya, paling tidak hingga taraf minimal. Dengan kata lain civil society adalah sebentuk model masyarakat yang di dalamnya tegak "negara institusional". Institusi dalam arti modern; parlemen, lembaga peradilan yang independen, kepartaian, asosiasi, ormas dan sebagainya.

Kita bisa mengamati kondisi non-demokratis di negara-negara yang penduduknya sebagian besar umat Islam dari dua sisi; analisis politik politikideologis dan analisis sosial-budaya. Yang pertama membahas seputar fenomena politik dan ideologi sebagai ekspresi dari pertarungan antar kekuatan dan kepentingan baik yang bersifat nasional, regional maupun internasional. Sedangkan yang kedua, yakni analisis sosial-budaya lebih memperhatikan kerangka sosial dan ranah kebudayaan dalam fenomena yang kita kaji, dan selanjutnya analisis ini memfokuskan diri pada elemen-elemen interennya. Dan hal ini harus diyakini bahwa konsistensi pada dua analisis tersebut merupakan keharusan untuk memperbesar kemungkinan mendekati tema ini. Kajian politik-ideologis memang harus terlebih dahulu dilakukan sebagai landasan deskripsi metodologis, kemudian dikembangkan ke arah interpretasi praksis dalam ranah sosial-budaya.

Hubungan antara Islam dan demokrasi atau dengan kata lain, potensi Islam demokratik sebagai agama, budaya dan peradaban selalu, menjadi isu kontroversial. Dalam sebuah perdebatan, teori dan praktek tida dapat dipisahkan, seperti masalah-masalah agama dan kultur politik. Sebagian orang melihat Islam sebagai doktrin (real Islam), seperti yang ada dalam ayat AlQur'an atau Sunah yang otentik. Sementara yang lain melihat Islam sebagai apa yang disebut 'Islam dalam sejarah'.

Bagaimanapun, referensi terhadap "Islam as such", Islam yang sesungguhnya dan 'Islam Historis', digunakan secara sangat terbatas dan kurang relevan untuk konteks saat ini. Yang kita hadapi saat ini adalah perdebatan yang mengakar sepanjang zaman modern. Merefleksikan cita-cita modern dan mencerminkan pembedaan pendangan mengenai apa makna menjadi seorang muslim dan bagaimana membangun tatanan islami. Karena itu, kita tidak sedang membicarakan Islam secara garis besar, tetapi kita membicarakan kaum Muslim -karena sebagian besar adalah kelas menengah perkotaan dan melek huruf-, yang dalam hubungannya dengan masalah-masalah tertentu mengenai ekonomi, sosial, budaya dan politik, menginterpretasikan sumber-sumber 
kekuasaan untuk mendefinisikan seperti apakah seharusnya atau seperti apakah bentuk tatanan the ideal concept of Islamic civil society.

\section{E. Islamic Studies Challenge; from Law and Ethics to Human Rights and Civil Society ${ }^{37}$}

Beberapa pemikir Muslim kontemporer, sebut saja di antaranya Fazlur Rahman, Mohammad Arkoun, Hasan Hanafi, Muhammad Syahrur, Abdullah Ahmed An-Na'im, Riffat Hassan, Fatima Marnisi, Nasr Hamid Abu Zaid, Thoha Abdur Rahman, Yahya Muhammad, menyoroti secara tajam paradigma keilmuan Islamic Studies khususnya paradigma keilmuan fikih. Dokumentasi rekam-jejak ilmu fikih kerapkali menjadi titik sentral yang selalu menarik untuk dikaji. Namun sayang, sangat jarang yang mengkaitkan ilmu hukum ini dengan kesadaran moral. Maka tak heran jika dalam beberapa kasus terjadi polemik pemikiran dan hasil yang kontroversial.

Salah satu dari sekian banyak kasus yang menggeletik naluri berpikir akademik kita adalah seputar kajian bidang kehukuman. Kekhawatiran Prof. Yudian Wahyudi. Ph. D., mengenai perkembangan keilmuan Islam, khususnya di Indonesia mengenai kajian ilmu Ushul Fikih patut dan menarik untuk ditindaklanjuti. Menurut beliau, dalam "pertaubatan epistemologis", yaitu penyatuan kembali metafisika dan fisika dalam kurikulum IAIN/UIN, umat Islam Indonesia suka "menggertak" dengan istilah-istilah keren yang seringkali hanya "comotisme". Salah satu slogan "comotis" itu adalah hermeneutika. Seolah-seolah hermeneutika tidak bermasalah jika begitu saja diterapkan

37 Penulis sengaja tidak menerjemahkan judul sub tema tersebut ke dalam bahasa Indonesia. Hal ini dikarenakan terdapat beberapa point penting yang penulis anggap sebagai informasi internasional terkait kajian Islamic Studies di era kontemporer. Law, Ethics, Human Rights dan Civil Society merupakan tema-tema agung yang sampai detik ini -bahkan untuk masa yang akan datang- senantiasa mendapatkan peringkat istimewa untuk dikaji, dianalisa, dan bahkan didefinisikan kembali. Karena sejatinya keempat tema besar di atas tidak hanya dibahas dalam satu teritorial wilayah atau antar wilayah tertentu, namun di seluruh dunia dengan berbagai macam bahasa yang ada. Dengan demikian, sekiranya dari judul tersebut kita dapat memahami bahwa area kajian Islamic Studies memiliki posisi sentral di mata para pemikir dunia internasional.

Islamic Studies Challenge sebagai daya rangsang yang bertujuan untuk melacak dan mengembangkan gagasan mengenai: 1) The Ideal Concept of Islamic Law. 2) The Ideal Concept of Islamic Ethics. 3) The Ideal Concept of Islamic Human Rights. 4) The Ideal Concept of Islamic Civil Society. 
pada Al-Qur'an. Di sisi lain, sejumlah profesor "propagandis" hermeneutika mengkritik ushul fikih. Di sini terjadi pendangkalan ganda. Ushul fikih sebagai metode tafsir belum sepenuhnya dipahami dengan utuh, tetapi sudah hendak diganti dengan ilmu "baru" tetapi pinggiran. Pendangkalan ganda ini terjadi karena propagandis hermeneutika itu pada umumnya bukanlah doktor hermenutika, apalagi doktor ushul fikih. ${ }^{38}$

Tidak berhenti di situ, etika selama ini sama sekali tidak mendapatkan porsi maksimal dalam kajian keislaman di PTAI. Etika di Indonsia khususnya di PTAI tidak dipandang sebagai sebuah disiplin keilmuan yang independen. Sangat disayangkan padahal etika dalam dua abad terakhir menjadi bahasan yang memiliki kajian urgensi mendampingi kajian bidang kehukuman. Seharusnya PTAI di Indonesia menyadari bahwa etika harus dikembangkan, karena sejatinya etika Islam selama ini hanya dipandang sebagai sebuah perilaku dan bukan sebagai sebuah ilmu. Dengan jargon-jargon keislaman, PTAI di Indonesia lupa bahwa dimensi etis memiliki potensi luar biasa untuk membangun sebuah peradaban baru untuk manusia di dunia ini, khususnya dunia Islam. Kenyataan ini tidak lebih dari akumulasi masa lalu, dan apa yang terjadi dalam kenyataan PTAI di Indonesia hanyalah sebentuk romantisme masa lalu. Miris, juga ironis.

Jika kita baca Great Traditions in Ethics ${ }^{39}$ karya gabungan dari Theodore

38 Baca: Yudian Wahyudi, Ushul Fikih versus Hermeneutika, (Yogjakarta: Nawasea Press, 2007).

39 Sebagai bukti akademik, penulis akan memetakan konten dari buku tersebut; Plato dengan Knowledge and Virtue, Aristotle dengan Moral Character, Epicurus dengan The Pleasant of Life, Saint Agustine dengan The Love of God, Saint Thomas Aquinas dengan Morality and Natural Law, Thomas Hobbes dengan Social Contract Ethics, Joseph Butler dengan Conscience in Morality, David Hume dengan Morality and Sentiment, Immanuel Kant dengan Duty and Reason, John Stuart Mill dengan The Great Happines Principle, Soren Kierkegaard dengan The Leap of Faith, Karl Marx dengan Morality as Ideology, Henry Sidwick dengan Utilitarianism Revised, Friedrich Nietzsche dengan The Transvaluation of Values, Jhon Dewey dengan Scientific Method in Ethics, G. E. Moore dengan The Indefinability of Good, W. D. Ross dengan Prima Facie Duty, A. J. Ayer and C. L. Stevenson dengan Ethics as Emotive Experession, Jeal Paul Sartre dengan Radical Freedom, Kurt Baier dengan Good Reasonsin Ethics, Jhon Rawls dengan Ethics and Social Justice, Philippa Foot dengan Moral Virtue and Human Interest,Anette Baier dengan Ethics as Trusting in Trust, dan William K, Frankena dengan The Concept of Morality.Lihat: Denise, Peterfreund, White, Great Traditions in Ethics, (USA: Wadsworth, 1999).

Maka pertanyaanya adalah di mana Al-Syafi' i? Di mana Al-Ghazali? Di mana Ibnu Rusyd? Di mana Al-Farabiy? Di mana Al-Kindiy? Dst.. Jikapun kita meyakini kesemuanya memiliki 
C. Denise, Sheldon P. Peterfreund dan Nicholas P. White, kita tidak menemukan bahasan etika Islam di dalamnya. Sebagai umat Islam, tentu tidak santun dengan beropini bahwa mereka sengaja tidak memasukkan etika Islam ke dalam tulisan mereka sebab mereka tidak paham akan Islam itu sendiri. Sekali lagi, inilah bentuk dan gaya berpikir umat Islam yang kerapkali enggan untuk membaca secara bijak. Menurut hemat penulis, maklum saja jika karya dari ketiganya tidak melirik etika versi Islam, karena memang etika dalam Islam selama ini tidak dipandang sebagai sebuah ilmu pengetahuan. Uniknya, para pemikir Islam klasik pun luput dengan fenomena ini. Kalau pun disinggung, etika hanya diposisikan sebagai sebuah perilaku yang acap kali disandarkan dengan nilai-nilai teosofis.

Perpaduan Hukum dan Etika merupakan upaya bijak, berdiri sendiri namun saling mengisi, bisa dibedakan namun tidak dapat dipisahkan. Jika selama ini hukum diposisikan hanya sebagai sebuah ilmu, maka sudah saatnya ia difungsikan sebagai sebuah laku. Dan sebaliknya, jika etika selama ini hanya difungsikan sebagai sebuah laku, maka saat ini ia harus diposisikan sebagai sebuah ilmu (ethics as a independent science). Sehingga insan akademisi Indonesia mampu menerapkan moral justification and the justification of morals untuk mensukseskan the social function of morality.

Sebagai sebuah teori epistema hukum yang baru, etika harus dikonsepkan berdasarkan nilai-nilai kemanusiaan. Karena nilai-nilai kemanusiaan adalah muara pertemuan antara tekstur kebenaran berhukum dalam agama dan filsafat. Kebenaran relasional merupakan perpaduan nilai etik dalam berhukum antara agama dan filsafat. Oleh karena itu, etika sebagai epistemologi harus juga memiliki formulasi netral antara agama dan filsafat, dengan menjadikan nilai-nilai kemanusiaan sebagai hukum universal. Adapun proses justifikasi yang lahir dari formula-formula tersebut, merupakan aktifitas berhukum demi mewujudkan manusia yang beretika.Formulasi etika sebagai wajah baru epistemologi bagi hukum menghadirkan varian formula dalam pandangan umum rasional melalui pengamatan moral. Artinya formula-formula tersebut menjadi bingkai konseptual yang rasional dalam sistem-sistem moral.

konsep akhlak, atau moral-etik, maka itu berarti kita masih belum berhasil membaca karya mereka dengan baik dan benar. Sebab itu, PTAI di Indonesia harus segara mulai memikirkan dan mempertimbangkannya sebagai bagian Studi Islam yang independen. 
Berdasarkan dari uraian di atas pada sub tema Law and Ethics; Syari'a and Philoshopical Diealectics, serta kegelisahan akademik yang baru saja disinggung, maka PTAI di Indonesia harus segera melakukan langkah-langkah kongkret agar studi Islam versi PTAI segara bisa dinikmati oleh para pegiat kajian, tidak hanya di Indonesia namun juga di kancah internasional.

Pesan kemanusiaan dan keadilan yang melekat dalam Al-Qur'an yang senantiasa disebut dengan "rahmatan lil 'alamin", hanya dapat dipahami dengan baik jika para penafsir kitab suci dan khasanah pikiran Islam klasik mampu memahami epistemologi masing-masing disiplin ilmu dengan benar. Hanya dengan demikian, apa yang dicita-citakan selama ini, yakni transformasi sosial yang progresif dan humanisasi ilmu-ilmu Islam dapat dirumuskan dengan baik.

Berbeda dengan kasus etika di atas, kajian mengenai human rights and civil society jauh lebih berkembang. Sebut saja Hasan Hanafi dengan Cultures and Civilizations $^{40}$ dan Islam in the Modern World, ${ }^{41}$ dan Mohammed Arkoun dengan Humanisme et Islam ${ }^{42}$, Abdullah Ahmed An-Na'im dengan Toward an Islamic Reformation $^{43}$, serta sebuah karya kompilasi yang diedit oleh John L. Esposito dengan Islam and Development, Religion and Sociopolitical change ${ }^{44}$, menjadi bukti bahwa perubahan citra sosial keagamaan menuju masyarakat madani merupakan cita-cita yang harus segera diwujudkan.

Tidak bermaksud mengucilkan para pemikir Islamic Studies di PTAI, namun harus diakui bahwa nasib kajian mengenai human rights and civil society tidak jauh berbeda dengan etika, tidak komprehensif, tidak pula teratur dan terukur. Kajian the human rights versi Islam dalam studi Islam internasional masih jarang, bahkan sangat susah untuk ditemukan. Jack Donnelly dalam Universal Human Rights in Theory and Practice ${ }^{45}$ membahas tentang sub tema Islam and Human Rights tidak lebih hanya dalam empat halaman saja (72-76).

${ }^{40}$ Hasan Hanafi, Cultures and Civilizations, (Kairo: Al-Kitab Publisher, 2007).

41 Hasan Hanafi, Islam in the Modern World, (Kairo: Dar Kebaa, 2000).

${ }^{42}$ Mohammed Arkoun, Humanisme et Islam, Combats et Propositions, (Paris: Librairie Philosophique J. Vrin, 2006).

43 Abdullah Ahmed An-Na'im, Toward an Islamic Reformation, op. cit.,

44 Jhon L. Esposito, Islam and Development, Religion and Sociopolitical Change, (New York: Syracuse University Press,1980).

45 Jack Donnelly, Universal Human Rights in Theory and Practice, (London: Cornel University Press, 2003). 
Berbeda dengan Jack Donnelly yang masih memberikan sedikit ruang kajian human rights dalam Islam, Carlos Santiago Nino dengan The Ethics of Human Rights $^{46}$ sama sekali tidak menyinggung tentang Islam dalam bab-bab dan sub tema kajiannya. Bahkan A. Belden Fields dengan Rethinking Human Rights for The New Millenium ${ }^{47}$ pun juga tidak memasukkan tema human rights Islam dalam penelitiannya.

Dari beberapa kasus di atas, kita harus menyadari bahwa memang kajian mengenai human rights and civil society dalam khasanah pemikiran Islam tidak dapat dilacak dengan jelas. Bahkan jangankan konsep metodologisnya, tema kemanusiaan pun dirasa alpa, sehingga Hasan Hanafi dalam Dirâsât Islâmiyahnya merasa perlu untuk menjelaskan mengapa kajian kemanusiaan bisa alpa dari khasanah pemikiran Islam klasik. ${ }^{48}$ Barangkali ini pun sama menggelitiknya dengan etika. Islam yang selama ini diyakini sebagai agama rahmat alam semesta, namun umatnya belum tampil percaya diri dengan gagasan etika dan hak-hak asasi manusia.

Berangkat dari kegelisahan akademik di atas, seharusnya kajian human rights and civil society di PTAI harus mendapatkan perhatian lebih agar mampu mengimbangi terma-terma hukum yang selama ini seolah menjadi slogan andalan dari segenap PTAI di Indonesia. Jika selama ini kajian mengenai human rights and civil society hanya dijadikan sebagai bumbu pemanis ala kadarnya, bahkan tidak dimasukkan dalam daftar pembelajaran, kini saatnya lah melihat human rights and civil society sebagai sebuah ilmu baru. Sebuah ilmu yang harus segera dikonsepkan, lalu diajarkan kepada seluruh mahasiswa, baik strata 1, 2 bahkan 3. Bukan tidak mungkin, ke depannya tema-tema inilah yang akan menjadi primadona kajian internasional, menggantikan terma hukum saat ini. Dan sekali lagi, PTAI di Indonesia sebagai lembaga perguruan tinggi agama Islam harus mampu memiliki karakteristik metodologis tersendiri. Agar Islam tidak disalah pahami karena alpa dari kajian-kajian kemanusiaan.

\footnotetext{
${ }^{46}$ Carlos Santiago Nino, The Ethics of Human Rights, (New York: Oxford University Press, 1993).

47 A. Belden Fields, Rethinking Human Rights for The New Millenium, (Palgrafe Macmillan, tt.).

48 Hasan Hanafi, Dirâsât Islâmiyah,(Kairo: Maktabah Angelo, tt.), hal. 393-415.
} 


\section{F. Penutup}

Rekonstruksi nalar keagamaan merupakan titik pijak untuk memotret tekstur kebenaran ketika manusia berupaya mendialektikakan antara agama dengan realita. Upaya menghadirkan pembacaan baru terhadap korpus-korpus Islam klasik merupakan sebuah keniscayaan. Hal ini bertujuan agar nilai-nilai kemanusiaan yang selama ini mengendap dapat dientaskan lalu dientitaskan.

Kala kita cermati dengan lebih teliti, gagasan kewajiban patuh hukum sebenarnya sudah dikonsepkan oleh para pakar praktisi hukum jauh sebelum Immanuel Kant; Imam Syafi'i misalnya. Dalam Treatise-nya, Imam Syafi'i menyebutkan bahwa kita wajib berhukum dengan kebenaran; baik lahir maupun batin. Tentu hal ini dapat dibenarkan. Karena jika hukum tidak dipahami sebagai sebuah kewajiban, maka itu berarti ia tidak dimengerti sama sekali.

Sebagaimana runtutan fase pemaknaan hukum di atas, dapat ditegaskan bahwa teori etika hukum merupakan hasil dari inter-epistema tekstur kebenaran antara agama dan filsafat dalam memandang sebuah hukum. Jika tekstur kebenaran hukum agama yang terbagi menjadi statis permanen dan dinamis imanen, serta tekstur kebenaran hukum dalam filsafat yang lebih bersifat praktikal-eksperimental, sejatinya antara syari'at dan filsafat samasama menjadikan etika sebagai nilai paripurna sebuah hukum.

Karakteristik paling esensial dari hak asasi manusia dalam Islam adalah bahwa hak-hak tersebut merupakan sebuah kewajiban yang terhubung langsung dengan nilai-nilai moral dalam pesan-pesan profetik hukum Islam. Sejatinya konsep hak asasi manusia (human rights) merupakan buah benih dari martabat manusia (human dignity) yang pertama kali ingin ditanamkan. Ini artinya bahwa hak asasi manusia adalah formula etik yang dengan berbagai teksturnya mencitakan manusia yang bermartabat dan mampu mengatasi segala harga.

Tekstur baru Studi Islam "from law and ethics to human rights and civil society" harus senantiasa mampu memotivasi untuk terus berproses dalam membaca yang tak tertulis, melihat yang tak tampak, mendengar yang tak bersuara, serta menyadari apa yang selama ini luput dari penghayatan sejati.

Without Law, Ethics, Human Rights and Civil Society, We Have to Pray for the Dignity of Every Human Being...!!! 


\section{DAFTAR PUSTAKA}

Abootalebi, Ali R. 1995. Democratization in Developing Countries: 1980-1989, Journal of Developing Areas 29, 1995.

Al-Ghazali, Abu Hamid. 2008. al-Mankhûl min Ta'lîqât al-Ushûl, Beirut: Maktabah 'Ashriyah

. 2011. al-Mustashfa min 'Ilmi al-Ushûl, Beirut: Dar An Nafa'es

Al-Jabiri, Muhammad Abid. 2011. Arab Ethical Reason (al-'Aql al-Akhlâqiy al'Arabiy), Beirut: Markaz Dirasat Al-Wahdah Al-Arabiah . 2002 Problem Demokrasi dan Civil Society, dalam Islam, Liberalisme, Demokrasi, Jakarta: Paramadina

Al-Syafi'i, Muhammad Bin Idris. 2005. Al-Risâlah, Kairo: Maktab Dar Al-Turats Al-Taftazaniy, Sa'duddin Bin Umar. 2005. Syarh al-Talwîh 'ala Taudlîh, Beirut: Al-Maktabah Al-'Ashriyaah

Al-Thawil, Taufiq. tt.Falsafah al-Akhlâq Nasy'atuhâ wa Tathawaruhâ, Kairo: Dar Al-Tsaqafah

An-Na'im, Abdullahi Ahmed, 1992. Toward an Islamic Reformation, Civil Liberties, Human Rights and International Law, Kairo: American University

Arkoun, Mohammed. 2006.Humanisme et Islam, Combats et Propositions, Paris: Librairie Philosophique J. Vrin

Bakir, Herman. 2009. Filsafat Hukum: Desain dan Arsitektur Kesejarahan, Bandung:

Refika Aditama

Boutroux, Emile. 1971.La Philosohie De Kant, dialihbahasakan Falsafatu Kant oleh Usman Amin, Kairo: Al-Haiah Al-Mashriyah Al-Amah

Denise, Peterfreund, White. 1999. Great Traditions in Ethics, USA: Wadsworth

Donnely, Jack, 2003. Universal Human Rights in Theory and Practise, London:

Cornell University press

Ernst, Carl W.2003. Following Muhammad: Rethinking Islam in The Contemporary World, Capel Hill-London: The University of North Carolina Press

Esposito, Jhon L., 1980. Islam and Development: Religion and Sociopolitical Change, New York: Syracuse University Press

Fakhry, Majid. 1983. A History of Islamic Philosophy, New York: Columbia University Press

Fields, A. Belden. tt.Rethinking Human Rights for The New Millenium, Palgrafe Macmillan 
Forsyth, James. 2003. Psycological Theories of Religion, New Jersey: Prentice Hall Gaita, Raimond. 2002. A Common Humanity: Thinking about Love and Truth and Justice, London: Routledge

Gellner, Ernest. 1991. Civil Society in Historical Context, International Social Science Journal, Agustus 1991.

Hanafi, Hasan. 2007. Cultures and Civilizations, Kairo: Al-Kitab Publisher .tt. Dirâsât Falsafiyah, Kairo: Maktabah Al-Angelo Al-Masriyah, tt. .tt. Dirâsât Islâmiyah, Kairo: Maktabah Angelo, tt. 2000. Islam in the Modern World, Kairo: Dar Kebaa 2005.min al-Nash ilâ al-Wâqi', Kairo: Markaz Al-Kitab

Hegel, G. W. F. 2003. The Phenomenology of Mind, New York: Dover Publication Kant, Immanuel. 1956. Critique of Practical Reason, USA: The Liberal Arts Press 2003. Perpetual Peace, dalam buku Philosophy and Revolution from Kant to Marx oleh Stathis Kouvelakis, New York: Verso 2005. The Moral Law (Groundwork of The Metaphysic of Morals), London: Routledge.

Lewis, Bernard, 2004. The Crisis of Islam, New York: Random House

Miller, Fred D., Jr. 1995. Nature, Justice and Rights in Aristotle's Politics, New York: Oxford University Press, 1995.

Mortiner, Edward. 1983. Islam and Human Rights, dalam Index on Censorship 12 , no. 5

Nino, Carlos Santiago, 1993. The Ethics of Human Rights, New York: Oxford University Press

Rachels, James. 2003. The Elements of Moral Philosophy, diterjemahkan Filsafat Moral, Yogyakarta: Kanisius

Rawls, Jhon. 1971. A Theory of Justice, USA: Havard University Press

Rex Brinen, Bahgat Koraniy, dan Paul Noble. 1995. Introduction, Theoritical Perspectives on Arab Liberalization and Democatization, dalam, eds. Political Liberalization and Democratization in the Arab World: Theoritical Perspective, Vol.. I, Lynne Rienner, Boulder

Sprague, Elmer. 1976. Knowledge and Value, New York: Harcourt-Brage \& World Wahyudi, Yudian. 2007. Ushul Fikih versus Hermeneutika, Yogjakarta: Nawasea Press

Zuhailiy, Wahbah. 1986.Ushul al-Fiqh al-Islâmiy, Beirut: Dar el-Fikr 
212 Millah Vol. XV, No. 2, Februari 2016 